\title{
Diversity analysis of antagonistic microbes against bacterial leaf and fungal sheath blight diseases of rice
}

\author{
Chinnaswami Kannan ${ }^{1 *} \mathbb{0}$, Divya Mishra ${ }^{2}$, Gonuguntala Rekha ${ }^{3}$ Pesari Maruthi ${ }^{1}$, Hajira Shaik ${ }^{3}$ and \\ Raman Meenakshi Sundaram³
}

\begin{abstract}
Background: Biocontrol is an effective strategy in the integrated management of plant diseases, now more as a necessity than choice, in the present era of environmental and health awareness. Microbial diversity is a wonder by nature that inspires to explore and accordingly, the diversity analysis of the isolated microbes revealed their morphological and molecular differences. The DNA provides a common platform to store the microbial information in the form of databases in public domain that can be used by anyone from anywhere.

Results: Exploration for native microbes in the present study resulted in isolation of different isolates of Trichoderma and Bacillus. The microbes were identified using morphological traits and molecular markers and the key conserved $18 \mathrm{~S}$ and $16 \mathrm{~S}$ gene sequences submitted with the appropriate repositories. Nucleotide analysis indicated a close phylogenetic relationship between BIK 2 and BIK 3 (Bacillus isolates) and within all the 5 Trichoderma isolates. The percent disease reduction of Rhizoctonia solani and Xanthomonas oryzae pv. oryzae (Х०O) was more in plants treated with consortia of the Trichoderma (61.13\%) and Bacillus (53.59\%) isolates, respectively. Screening of plant growth promotion activities, percentage increase in root (41.00\%) and shoot length (44.77\%) were found to be maximum in Trichoderma consortia treated plants.

Conclusions: Three Bacillus and one Trichoderma strains, viz., B. velezensis, B. subtilis and B. paralicheniformis and Trichoderma asperellum, were identified and found to be effective against $R$. solani and Xoo pathogens of rice. In vitro and in vivo studies indicated that TAIK1 and BIK3 were found to be the most potential isolates among others isolated. Ability to improve plant growth was more pronounced by consortia of microbes.
\end{abstract}

Keywords: Biocontrol, Trichoderma, Bacillus, Diversity analysis, Bacterial blight, Sheath blight

\section{Background}

Agricultural soils are the most dynamic in nature; however, the micro-flora and fauna that impacts the quality and yield of the crops grown generally remains a mystery. Increasing population and decreasing agricultural soil availability result in an undue increase in demand for food, inviting an extremely intense cultivation. This led to

\footnotetext{
*Correspondence: agrikannan@gmail.com

${ }^{1}$ Department of Plant Pathology, ICAR-IIRR, Hyderabad, Telangana, India Full list of author information is available at the end of the article
}

the use of more chemical inputs causing severe stress on the environment and human health (Chukwu et al. 2019). In this context, the use of microbes as biopesticides to protect them from diseases, improve yield quality in a sustained eco-friendly manner, plays a very important role in the process of providing food security for the everincreasing population (Mukherjee et al. 2013).

Rice is the leading staple crop of the world and consumed by more than half of Indian population. It is attacked by various fungal, bacterial and viral pathogens, incurring huge loss to crop quality and quantity (Köhl et al. 2019). Development of resistant varieties, 
wherever possible, is considered a welcome replacement for synthetic pesticides. However, there are some diseases like sheath blight and false smut in rice, for which donors with strong resistance are not available. In addition, the breakdown of resistance in diseases like bacterial blight of rice (BB) and blast leads to significant loss to the farmers (Chukwu et al. 2019). Biological control using friendly microbes or their products to suppress the pathogens plays a crucial role in sustainable integrated management of plant diseases (Gnanamanickam 2009). Species belonging to the genera Trichoderma, Bacillus and Pseudomonas are more commonly found in the plant rhizosphere that help in the growth promotion of the plants and induce resistance/tolerance against biotic and abiotic stresses. These microbes suppress the pathogens either directly by contact or indirectly by releasing certain chemical compounds and releasing plant growth promoting hormones that helps in healthy growth and development of crops (Abo-Elyousr et al. 2019). They elicit defence system in plants by activating signal molecules that typically recognize pathogen, stimulate and initiate defence pathways. Use of conserved sequences, viz., 16S rRNA for bacterial isolates and internal transcribed spacer (ITS) regions for fungal isolates, complements their phenotypic characterization (Ashe et al. 2014). In addition, phylogenetic studies based on taxonomic markers specific for individual species and their multiple genes have been described as useful tools for molecular diversity studies (Youssuf et al. 2014). In the present study, specific primers for detection of endonuclease genes have been deployed in addition to primers for 16S rRNA to identify different isolates of Bacillus. Similarly, 18S rRNA gene, ITS1, 5.8S rRNA gene, ITS2 and $28 \mathrm{~S}$ rRNA gene sequences were deployed for identification of Trichoderma at species level. The present study was to isolate native Trichoderma and Bacillus isolates from the rhizosphere of different rice growing regions of Telangana, India, establishing their identity, potential for growth promotion and efficiency to suppress Xanthomonas oryzae pv. oryzae (Xoo) and Rhizoctonia solani, the 2 major pathogens causing bacterial blight and sheath blight diseases of rice, respectively.

\section{Methods}

\section{Microbial preparation}

Trichoderma and Bacillus isolates were obtained from the rice rhizosphere of different regions of Telangana State, using standard serial dilution method. Trichoderma specific medium (TSM) and peptone yeast extract medium (PYEM) were used as selective medium for isolation and purification of fungal and bacterial antagonists, respectively (Cavaglieri et al. 2004). Key morphological and microscopic characters were used for identification of
Trichoderma isolates (Gams and Bissett 1998), and Bacillus isolates (Sneath 1986). Scanning electron microscopy (SEM) was done as described by Bozzola and Russell (1999). Samples were fixed in $2.5 \%$ glutaraldehyde for $24 \mathrm{~h}$ at $4{ }^{\circ} \mathrm{C}$, followed by $2 \%$ aqueous osmium tetroxide for $4 \mathrm{~h}$. After dehydration in series of graded alcohols, the samples were mounted and observed in SEM (JEOL JSM-5600).

\section{Pathogens}

R. solani, collected from Plant Pathology Laboratory, Hyderabad (Yugander et al. 2015) and Xoo (Accession number: MZ158566), were used for the experimental study. Their pathogenicity was proved according to Koch's postulates on TN1 cultivar.

\section{Genomic DNA from bacterial and fungal antagonists}

Bacillus isolates, viz., B2, B3 and B4, and Trichoderma isolate T7 were cultured in Luria Bertani (LB) and potato dextrose broth (PDB), respectively. Bacillus cells were harvested by centrifuging at $8000 \times g$ for $10-15 \mathrm{~min}$ and fresh mycelial mats of Trichoderma were used for the isolation and purification of genomic DNA. NucleoSpin ${ }^{\circledR}$ genomic DNA isolation and purification kit (MacheryNagel) were used as per the manufacturer's instructions. The isolated DNA was quantified using both nanodrop spectrophotometer (Thermofischer) and $0.8 \%$ agarose gel pre-stained with ethidium bromide.

\section{PCR amplification}

Bacillus isolates were identified using amplification of $16 \mathrm{~S}$ rRNA $(\sim 1500 \mathrm{bp})$ by universal primer pairs $27 \mathrm{~F}$ (5'-AGAGTTTGATCMTGGCTCAG-3') and 1492R (5'CGGTTACCTTGTTACGACTT-3'). The polymerase chain reaction (PCR) mixture consists of 30-50 ng DNA template, $2.5 \mathrm{mM}$ dNTP mix, $0.5 \mu \mathrm{M}$ primers, $10 \mathrm{mM}$ Tris- $\mathrm{HCl} \mathrm{pH} 8.3,1.5 \mathrm{mM} \mathrm{MgCl}_{2}, 5 \mathrm{U}$ Taq polymerase. Amplification conditions were as follows: denaturation for $2 \mathrm{~min}$. at $94{ }^{\circ} \mathrm{C}$; 30 cycles of amplification; $40 \mathrm{~s}$. denaturation at $94{ }^{\circ} \mathrm{C} ; 45 \mathrm{~s}$. annealing at $54{ }^{\circ} \mathrm{C} ; 1 \mathrm{~min}$. extension at $72{ }^{\circ} \mathrm{C}$ followed by final extension $10 \mathrm{~min}$. at $72{ }^{\circ} \mathrm{C}$. In case of Trichoderma, $18 \mathrm{~S}$ rRNA gene (partial sequence), internal transcribed spacer $1,5.8 \mathrm{~S}$ rRNA gene internal transcribed spacer 2 (complete sequence) and $28 \mathrm{~S}$ rRNA gene (partial sequence) were amplified by using the primer combinations ITS1 (5'-TCCGTA GGTGAACCTGCGG-3') and LR3R (5'-GGTCCGTGT TTCAAGAC- $3^{\prime}$ ) with fragment size of $\sim 1200 \mathrm{bp}$; using the following conditions, viz., $1 \mathrm{~min}$ initial denaturation at $94{ }^{\circ} \mathrm{C} ; 30$ cycles of $1 \mathrm{~min}$. denaturation at $94{ }^{\circ} \mathrm{C} ; 1 \mathrm{~min}$ primer annealing at $50{ }^{\circ} \mathrm{C} ; 90 \mathrm{~s}$. extension at $74{ }^{\circ} \mathrm{C}$ and a final extension period of $7 \mathrm{~min}$. at $74{ }^{\circ} \mathrm{C}$. Size of the PCR amplicons were analysed on $1 \%$ agarose gel. 


\section{Purification of PCR product and sequencing}

PCR amplicon fragments were purified using Promega Wizard $^{\circledR}$ SV Gel and PCR Clean-Up System kit, and the purified products of about concentration 50-100 ng/ul were sequenced using Sangers sequencing method. The nucleotide sequences were submitted to NCBI GenBank database and NCBI accession numbers were obtained. These sequences were further aligned and compared with the sequences of Bacillus and Trichoderma species available with NCBI. NCBI BLAST homology searches of the respective gene sequences which performed to assess homologous sequences available in NCBI. Computational analysis of DNA sequence data, sequence editing, multisequence alignment and molecular phylogeny were performed using EMBL-EBI.

\section{In vitro inhibition of Xoo by Trichoderma and Bacillus sp.} Inhibitory efficiency of Trichoderma on Xoo was analysed using dual culture competition-suppression assay (Sinclair and Dingra 2017). A loop of individual isolates Trichoderma mycelia along with spore and Xoo was placed exactly opposite to each other on a Petri plate maintaining equidistance from centre, containing modified Wakimoto media (MWM). Control plate was maintained by inoculating Xoo alone. Radial growth of Xoo was measured in treated as well as control plate and percent inhibition was calculated by the formula (Gangwar and Sinha 2010)

$$
\text { Per cent inhibition }(\%)=\frac{C-T}{C} \times 100
$$

where $C=$ colony growth in centimetre in control plate, $T=$ colony growth in centimetre in treated plate.

Efficacy of $\mathrm{f}$ Bacillus on Xoo was established by slightly modifying the agar well diffusion technique (Sinclair and Dingra 2017). Four diffusion wells opposite sides to each other on PYEM plate containing one day old colony of Xoo were added with the broth of Bacillus. The suppression was observed as overgrowth of Bacillus isolates over Xoo. Quantitative estimation of Bacillus efficiency against Xoo was obtained by measuring the optical density $\left(\mathrm{OD}_{600 \mathrm{~nm}}\right)$ of broth containing Bacillus and Xoo. Bacillus isolates were grown on LB broth at $37{ }^{\circ} \mathrm{C}$ in rotatory shaker at $160 \mathrm{rpm}$ for $48 \mathrm{~h}$. Culture filtrates were obtained by centrifugation of broth containing culture @16,000 rpm for $10 \mathrm{~min}$ and filtered sterilized twice through $0.22 \mu \mathrm{m}$ filter. Different concentrations (10, 25, 50,75 and $100 \%$ ) of culture filtrate were tested to finalize the lethal concentration for pathogen. In $20 \mathrm{ml}$ of broth containing different concentrations of Bacillus filtrates, a $100 \mu \mathrm{l}$ of Xoo broth culture was added and kept for incubation at $28 \pm 2^{\circ}$ for $48 \mathrm{~h}$. Negative control was maintained with Xoo alone in the LB broth (Elshakh et al. 2016). $\mathrm{OD}_{600 \mathrm{~nm}}$ was measured after $72 \mathrm{~h}$ of incubation.

\section{In vitro inhibition of $R$. solani by Trichoderma and Bacillus}

sp.

Antagonistic potential of both the antagonists against $R$. solani was studied using dual plate competition assay (Marzano et al. 2013). Five mm mycelial discs of both Trichoderma isolates and $R$. solani were placed opposite to each other equidistance from centre of a Petri plate containing PDA. The radial growth of $R$. solani with Trichoderma isolates was recorded along with control. The efficiency of Bacillus isolates on $R$. solani was estimated in the similar method as done for Trichoderma sp. with slight modification to make up for the differences in the rate of growth of the Bacillus when compared to $R$. solani (Huang et al. 2012). R. solani was grown for $24 \mathrm{~h}$ at a corner of a plate with NA, followed by streaking a loop of individual Bacillus at the opposite edge. Plates with pathogen alone served as control. The plates were incubated at room temperature for 2 days, and thereafter, the radial growth of $R$. solani was measured and recorded.

Percentage inhibition was calculated for both the protocol using above-mentioned formula (Gangwar and Sinha 2010).

\section{Compatibility of consortia mixtures}

Isolates of Trichoderma and Bacillus were individually tested against each other for their compatibility (Siddiqui and Shaukat, 2003). Different isolates of Bacillus grown separately on PYEM plates were streaked perpendicular to each other on a fresh plate containing $20 \mathrm{ml}$ PYEM. Similarly, 5-mm disc from 7-day-old cultures of the isolates of Trichoderma grown separately was placed in a fresh plate containing PDA, maintaining equal distance with each other. Both the consortia were incubated at $27 \pm 2{ }^{\circ} \mathrm{C}$ (Fig. 1). Zone of inhibition, if any formed was measured as the incompatibility against the two antagonists. The test was replicated multiple times.

\section{Mass multiplication of antagonists for seed and soil application}

Antagonists slurry made from 4-day-old cultures was suspended in sterile water to make a uniform suspension and used for seed treatments. For soil application, the antagonists were cultured in their respective broths. About $100 \mathrm{ml}$ of broth $\left(\times 10^{6}\right.$ and $\times 10^{4} \mathrm{CFU} / \mathrm{ml}$, respectively, for Bacillus and Trichoderma) was mixed with $1 \mathrm{~kg}$ of powdered rice bran and carboxymethyl cellulose (CMC) @2 g/Kg. This mixture was used @100 g per pot as per the treatment schedule. Consortia of compatible microbes were formulated as above by mixing both the antagonists in their respective seed and soil formulations 

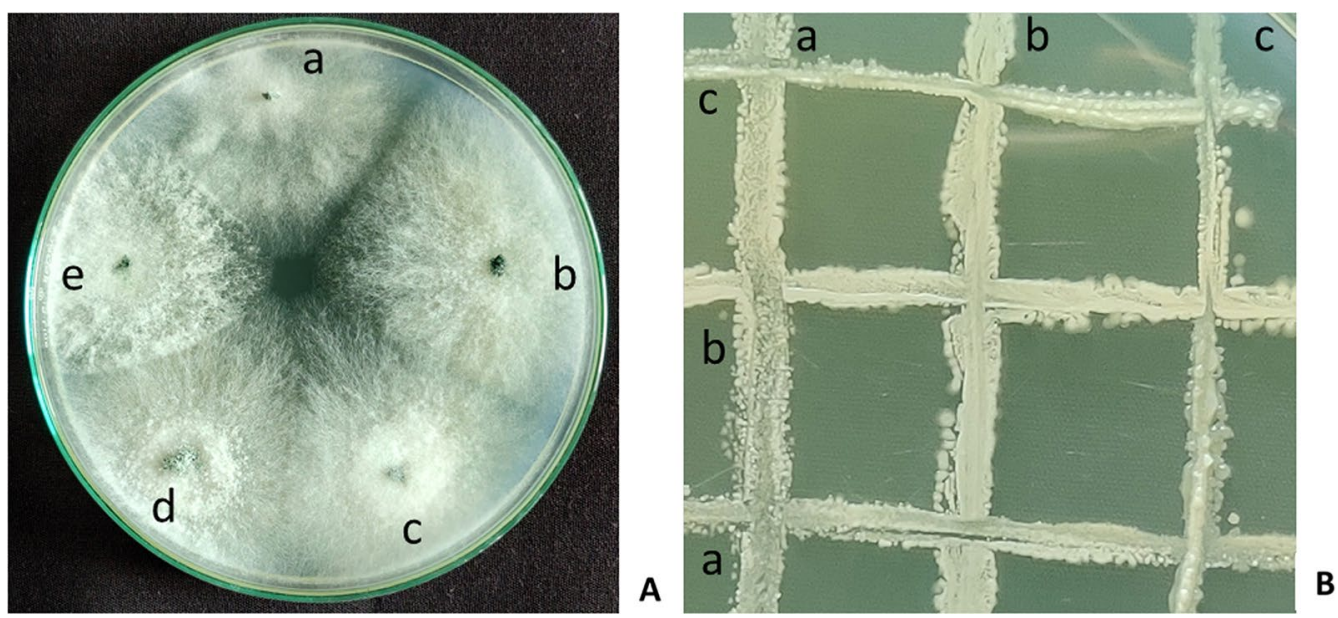

Fig. 1 Compatibility studies among the individual consortia of selected fungal and bacterial isolates. Note: Picture represents the consortia compatibility test among bioagents. A: Consortia of five Trichoderma isolates \{a: TAIK1, b: TAIK2, c:TAIK4, d: TAIK5 and e: TAIK3\} on PDA media B: Consortia of Bacillus \{a: BIK2, b: BIK3, c: BIK4\} isolates on PYEM. Compatibility of the isolates with each other is confirmed with no inhibition zone

in equal proportions. In all the above formulations, the inoculum density of $2.14 \times 10^{7} / \mathrm{ml}\left(\mathrm{OD}_{600 \mathrm{~nm}} \sim 1.0\right)$ for Trichoderma and $1.08 \times 10^{8} / \mathrm{ml}\left(\mathrm{OD}_{600 \mathrm{~nm}} \sim 0.4\right)$ for Bacillus were maintained in the liquid suspension (Beal et al. 2020).

In vivo screening of isolated antagonists against $X o o$ and $R$. solani in net-house

The experiments were conducted under controlled conditions in net-house. The seeds of susceptible rice cultivar TN were soaked in sterile water for $24 \mathrm{~h}$ and after draining the excess water, were mixed with the antagonist suspension (@10 ml $/ \mathrm{Kg}$ seeds) and incubated for $12 \mathrm{~h}$. Treated seeds were then kept on blotting paper to test the germination percentage. About 25 seeds from the initial lot were then placed in nursery trays and monitored for 10 days to calculate morphological parameters like seedling length, seedling dry weight, vigour index-1 (germination \% X seedling length) and vigour index-2 (germination \% X seedling dry weight). About 25-dayold seedlings from the nursery were transplanted in pots of size $30 \times 25 \mathrm{~cm}$ with about $5-7 \mathrm{~kg}$ of soil. Thirty days after transplanting (DAT), antagonists were applied to soil @ $10 \mathrm{~g} / \mathrm{Kg}$ of soil. The pathogens were inoculated at 40 DAT. Xoo was inoculated by leaf clipping method by diluting with $10 \mathrm{mM} \mathrm{MgCl}$ and maintaining the 0.5 $\mathrm{OD}_{600}$ (Ke et al. 2017). Inoculation of $R$. solani was done by placing about $0.5 \mathrm{mg}$ of sclerotia in rice sheath and covering it by moist cotton swab (Singh et al. 2002). The experiments were repeated during 2 seasons with 3 replications under controlled conditions in net-house and the values were averaged.

\section{Statistical analysis}

The experiments were conducted in completely randomized design (CRD) and data were subjected for one-way analysis of variance (ANOVA), using post hoc test with Duncan's multiple range test (DMRT) at $5 \%$ $(P \leq 0.05)$ significance level in SPSS 20.0.1 version. Correlation analysis and graphs were made using Microsoft excel 2019. Three replications were maintained during each experiment.

\section{Results}

Isolation and identification of isolated pathogens

The Trichoderma and Bacillus isolates collected from rice rhizosphere samples, one potential isolate of Trichoderma, viz., T7 and 3 isolates of Bacillus , viz., B2, B3 and B4, were considered for further studies on the basis of the growth rate, colony morphology and in vitro screening against the pathogens. Along with these selected isolates, 4 potential isolates of Trichoderma, viz., TAIK 1 (T. asperellum IIRRCK1), TAIK 2 (T. asperellum IIRRCK2), TAIK 3 (T. asperellum IIRRCK3) and TAIK 4 (T. asperellum IIRRCK4) obtained from the Department of Plant Pathology, Hyderabad, were used in the studies. The morphological features of the selected Trichoderma and Bacillus isolates were described (Tables 1,2). The microscopic features of TAIK 1 to 4 isolates have been described earlier in detail by Kannan et al. (2018). The key microscopic features of T7 were oval/round-shaped conidia, aggregated and irregularly branched conidiophores fertile at the tip, phialides were sigmoid, sparingly produced from the main axis and chlamydospores typically 
Table 1 Collection and identification of the isolated fungal antagonists

\begin{tabular}{|c|c|c|c|c|c|c|c|c|c|}
\hline \multirow{2}{*}{$\begin{array}{l}\text { Isolate } \\
\text { name }\end{array}$} & \multirow{2}{*}{$\begin{array}{l}\text { Scientific } \\
\text { name }\end{array}$} & \multirow{2}{*}{$\begin{array}{l}\text { Place of } \\
\text { collection } \\
\text { (latitude/ } \\
\text { longitude) }\end{array}$} & \multirow{2}{*}{$\begin{array}{l}\mathrm{NCBI} \\
\text { accession } \\
\text { number }\end{array}$} & \multicolumn{4}{|c|}{ Colony morphology in standard PDA medium } & \multicolumn{2}{|l|}{ Sporulation } \\
\hline & & & & Colour & Colony & $\begin{array}{l}\text { Radial } \\
\text { growth of } \\
\text { colony in } \\
36 \mathrm{~h}(\mathrm{~cm})\end{array}$ & Texture & $\begin{array}{l}\text { Colour of } \\
\text { spores }\end{array}$ & $\begin{array}{l}\text { Days for } \\
\text { maturation }\end{array}$ \\
\hline TAIK1 & $\begin{array}{l}\text { Trichoderma } \\
\text { asperellum } \\
\text { IIRRCK1 }\end{array}$ & $\begin{array}{l}\text { Hyderabad } \\
\left(17.3220^{\circ} \mathrm{N},\right. \\
\left.78.4023^{\circ} \mathrm{E}\right)\end{array}$ & MH825714 & Dark green & & $3.7 \pm 0.12$ & $\begin{array}{l}\text { Smooth } \\
\text { mat with } \\
\text { concentric } \\
\text { rings }\end{array}$ & $\begin{array}{l}\text { Yellowish } \\
\text { Green }\end{array}$ & 4 \\
\hline TAIK2 & $\begin{array}{l}\text { Trichoderma } \\
\text { asperellum } \\
\text { IIRRCK2 }\end{array}$ & $\begin{array}{l}\text { Hazaribagh } \\
\left(23.9925^{\circ} \mathrm{N}\right. \\
\left.85.3637^{\circ} \mathrm{E}\right)\end{array}$ & MH825715 & $\begin{array}{l}\text { Yellowish } \\
\text { green }\end{array}$ & & $3.2 \pm 0.08$ & Smooth mat & Light green & 3 \\
\hline TAIK3 & $\begin{array}{l}\text { Trichoderma } \\
\text { asperellum } \\
\text { IIRRCK3 }\end{array}$ & $\begin{array}{l}\text { Raipur } \\
\left(21.2514^{\circ} \mathrm{N}\right. \\
\left.81.6296^{\circ} \mathrm{E}\right)\end{array}$ & MH825716 & Light green & & $3.0 \pm 0.03$ & Smooth mat & Light green & 3 \\
\hline TAIK4 & $\begin{array}{l}\text { Trichoderma } \\
\text { asperellum } \\
\text { IIRRCK4 }\end{array}$ & $\begin{array}{l}\text { Rewa } \\
\left(24.5362^{\circ} \mathrm{N}\right. \\
\left.81.3037^{\circ} \mathrm{E}\right)\end{array}$ & MH825717 & Dark green & 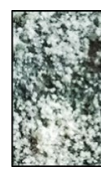 & $4.1 \pm 0.10$ & Fluffy mat & Dark green & 3 \\
\hline TAIK5 & $\begin{array}{l}\text { Trichoderma } \\
\text { asperellum } \\
\text { IIRRCK5 }\end{array}$ & $\begin{array}{l}\text { Hyderabad } \\
\left(17.3220^{\circ} \mathrm{N}\right. \\
\left.78.4023^{\circ} \mathrm{E}\right)\end{array}$ & MT802436 & Dark green & & $4.5 \pm 0.04$ & Smooth mat & Dark green & 2 \\
\hline
\end{tabular}

Table 2 Collection and identification of the isolated bacterial antagonists

\begin{tabular}{|c|c|c|c|c|c|c|c|}
\hline \multirow[t]{2}{*}{ Isolate code } & \multirow[t]{2}{*}{ Scientific name } & \multirow{2}{*}{$\begin{array}{l}\text { Place of collection } \\
\text { (latitude/longitude) }\end{array}$} & \multirow{2}{*}{$\begin{array}{l}\text { NCBI } \\
\text { accession } \\
\text { number }\end{array}$} & \multicolumn{4}{|c|}{ Colony morphology in PYEM } \\
\hline & & & & Colour & Colony & $\begin{array}{l}\text { Radial colony } \\
\text { growth in } 36 \mathrm{~h} \\
\text { (cm) }\end{array}$ & Texture \\
\hline BIK2 & B. velezensis IIRRCKB2 & $\begin{array}{l}\text { Karimnagar }\left(18.4386^{\circ}\right. \\
\left.\mathrm{N}, 79.1288^{\circ} \mathrm{E}\right)\end{array}$ & MW181655 & Grey white & & $1.5 \pm 0.03$ & $\begin{array}{l}\text { Round, smooth and } \\
\text { moist }\end{array}$ \\
\hline BIK3 & B. subtilis IIRRCKB3 & $\begin{array}{l}\text { Hyderabad } \\
\left(17.3220^{\circ} \mathrm{N}\right. \\
\left.78.4023^{\circ} \mathrm{E}\right)\end{array}$ & MW181668 & Off-white & & $2.1 \pm 0.10$ & Flat, opaque and dry \\
\hline BIK4 & $\begin{array}{l}\text { B. paralicheniformis } \\
\text { IIRRCKB4 }\end{array}$ & $\begin{array}{l}\text { Nalgonda }\left(17.0575^{\circ}\right. \\
\left.\quad \text { N, } 79.2684^{\circ} \mathrm{E}\right)\end{array}$ & MW180949 & Pinkish white & & $1.8 \pm 0.09$ & $\begin{array}{l}\text { Irregular and extra } \\
\text { slimy }\end{array}$ \\
\hline
\end{tabular}


absent. Bacillus isolates B 1 to 3 in were gram-positive, rod-shaped, spore-forming bacteria varying in size. However, they differed in the colony colour, viz., B2 was grey white, B3 was off-white, and B4 was pinkish white. SEM images obtained revealed that conidia of TAIK 1 were warted $(0.02 \mu \mathrm{m})$, oval in shape $(2.64 \mu \mathrm{m})$ with aggregated branched conidiophore $(15.7 \times 2.25 \mu \mathrm{m})$ and bottle-shaped clustered phialides. B3 colonies were rod-shaped, atrichous, with a size of $1.38 \times 0.75 \mu \mathrm{m}$ (Table 3).

\section{Sequence-based identity of Bacillus and Trichoderma isolates}

In addition to the morphological characterization of the experimental Bacillus isolates, amplification of $16 \mathrm{~S}$ rRNA and endoglucanase regions using specific primers

Table 3 Microscopic features of the two potential antagonists

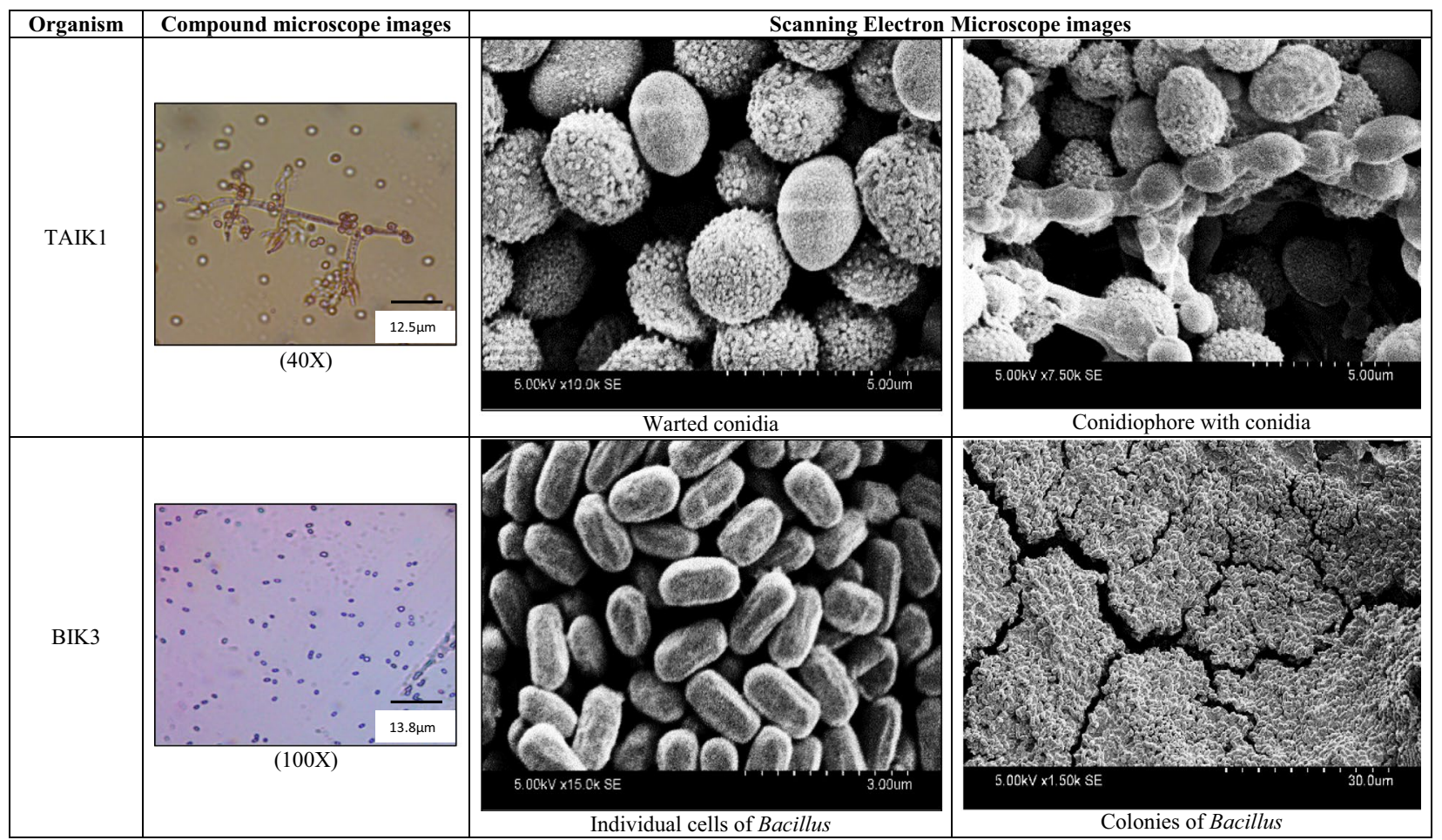

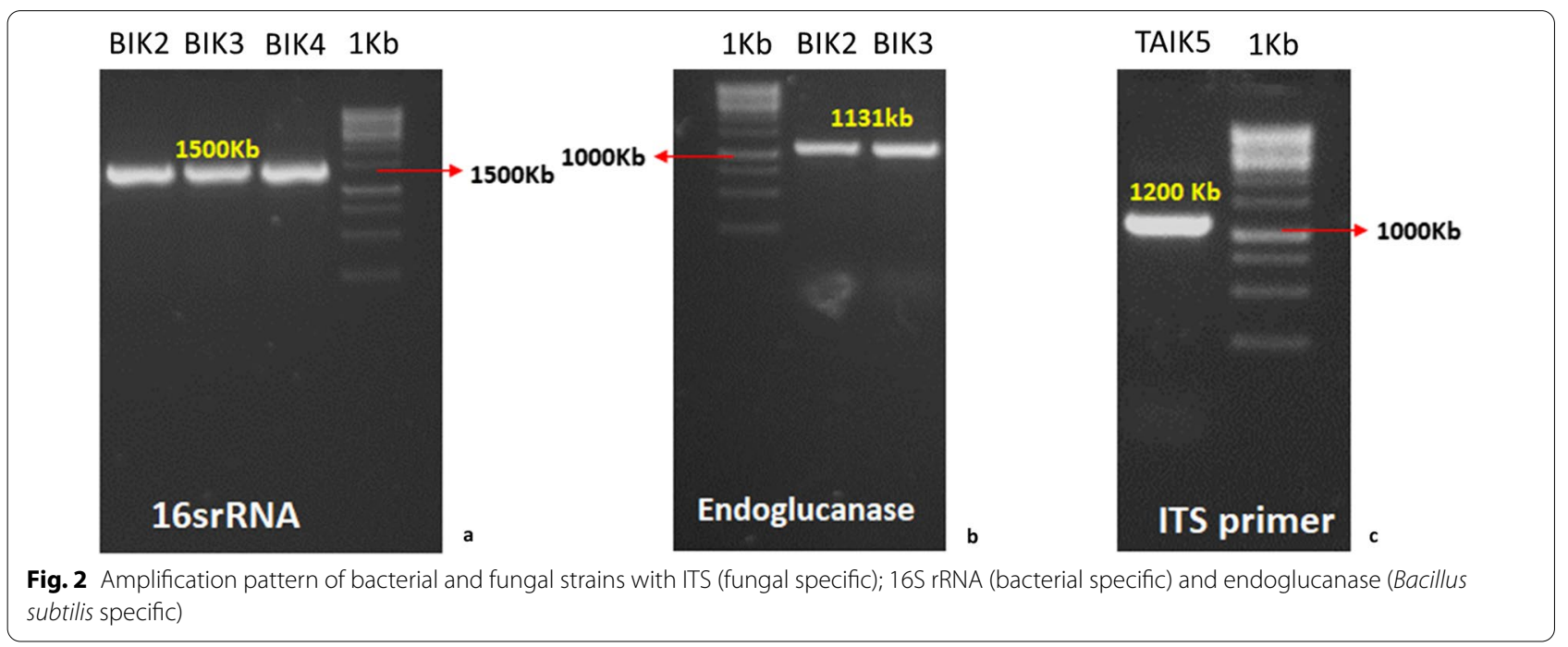




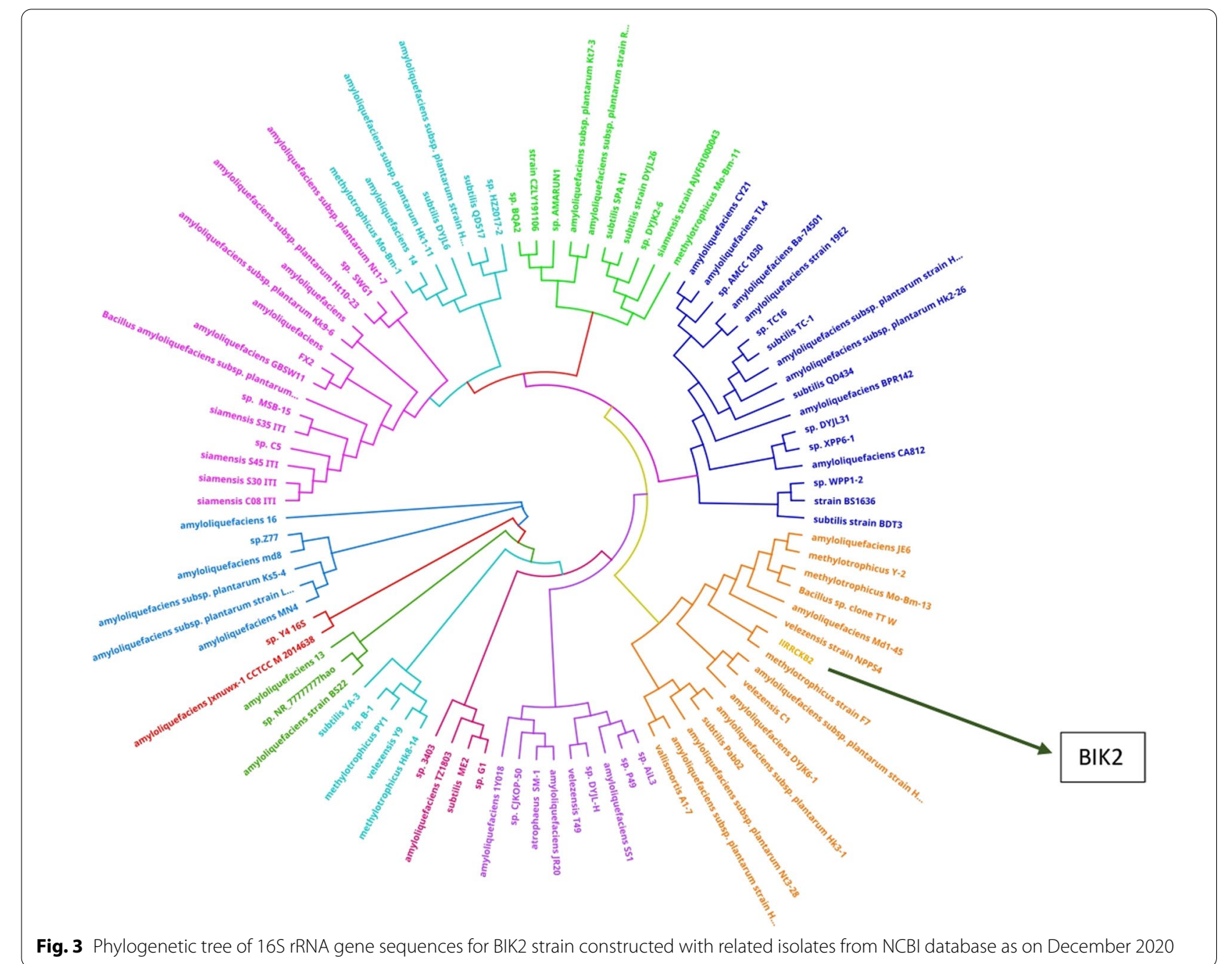

(Fig. 2a, b) and their alignment against related sequences in NCBI revealed a similarity index of $97-98 \%$ for B2 with B. velezensis (Fig. 3), 96-97\% for B3 with B. subtilis (Fig. 4) and 96\% for B4 with B. paralicheniformis (Fig. 5). They were named as BIK 2 (B. velezensis IIRRCKB2), BIK 3 (B. subtilis IIRRCKB3) and BIK 4 (B. paralicheniformis IIRRCKB4). Phylogenetic analysis within the species indicated that the two isolates, viz., BIK 2 and BIK 3 , were closely related with a sequence homology of $98.6 \%$, while they were 92-93\% with BIK 4. It can thus be concluded that BIK 2 and BIK 3 are genetically closer in comparison with BIK 4 isolate. In case of T7, the ITS region sequence alignment in the NCBI database indicated 98-99\% similarity with T. asperellum and named as TAIK 5 (T. asperellum IIRRCK5) (Figs. 2c and 6). In order to differentiate with other T. asperellum isolates from our study (Kannan et al. 2018), all the nucleotide sequences were aligned (TAIK 1, TAIK 2, TAIK 3 and TAIK 4 with TAIK 5) and results revealed a sequence homology of
98-99\% among the isolates, indicating genetic similarity within the isolates. The nucleotide differences among the Bacillus and Trichoderma strains have also been analysed (Fig. 7a and b, respectively).

\section{Growth inhibition of Xoo and $R$. solani by Trichoderma and Bacillus sp. in vitro}

Significant reductions in the growth rates of Xoo and $R$. solani over control with different Trichoderma isolates were observed initially in the dual culture plates and in later days of observation, the plates were completely covered by Trichoderma and an overgrowth of Trichoderma on Xoo colonies was observed. Among different isolates of Trichoderma and Bacillus, TAIK 1 was found to be significantly effective in inhibiting the growth of both the pathogens (Figs. 8a,c, 9a). Among Bacillus isolates, complete growth of BIK 3 upon Xoo was observed after $48 \mathrm{~h}$ (Fig. 8b) and the cultural filtrate (concentration 75\%) obtained from BIK 3 was the most efficient in reducing 


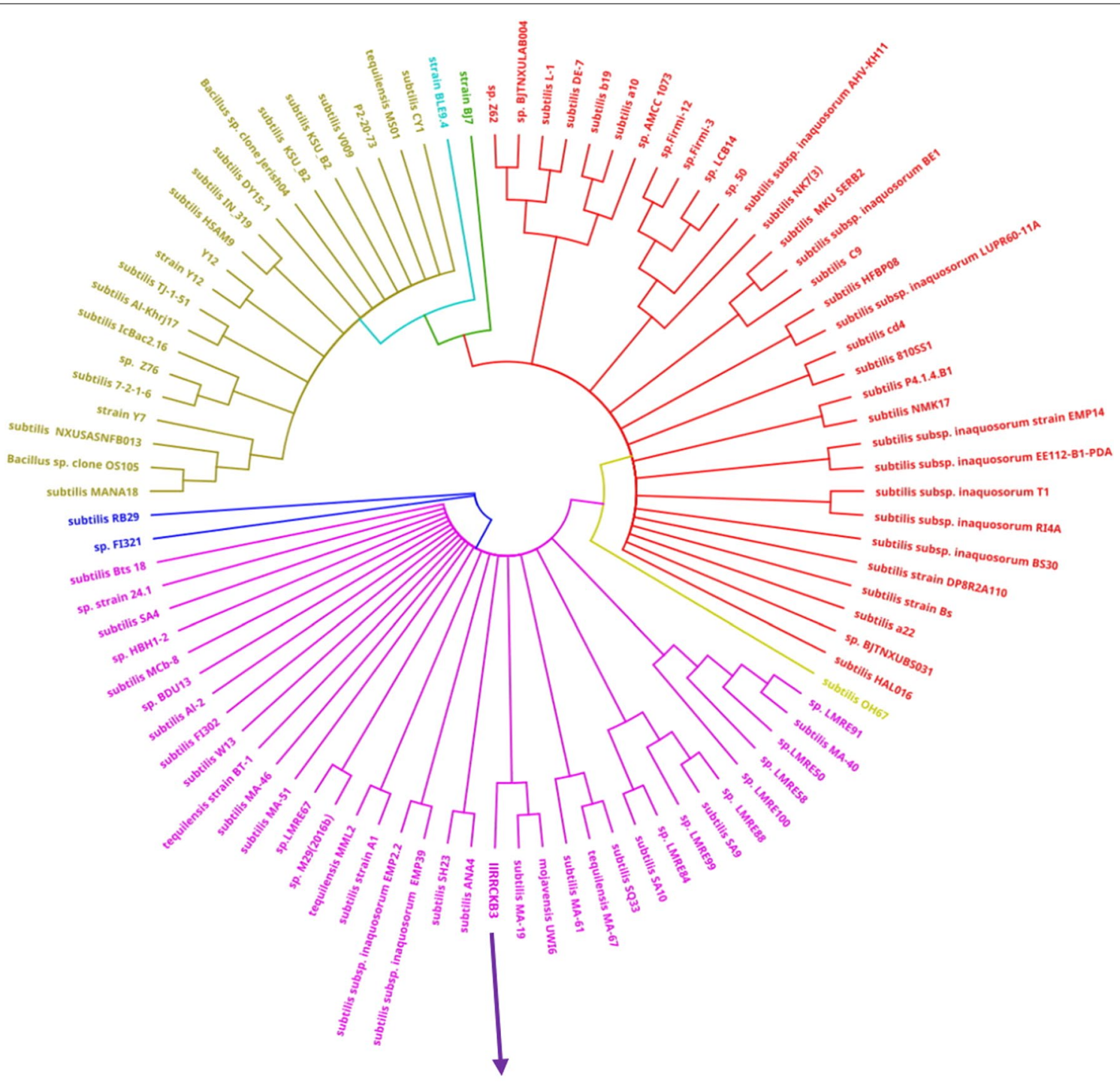

BIK3

Fig. 4 Phylogenetic tree of 16S rRNA gene sequences for BIK3 strain constructed with related isolates from NCBI database as on December 2020

the viable population of pathogen as compared with other cultures (Fig. 9b.A). The Bacillus isolates were also found to suppress $R$. solani and the inhibition zone and percentage of growth reduction was comparatively high in BIK 3 (Figs. 8d, 9b.B).

\section{Plant growth promoting activities of Trichoderma and Bacillus isolates}

All the cultures, in general, showed significant improvement in seed germination and further growth of rice seedlings. Based on initial 10 days parameters of seed germination and growth, vigour index- 1 and vigour index- 2 were found to be the highest in the consortia treatment of Trichoderma isolates. Further, TAIK 1 was found to be significantly better than the combined effect of Bacillus consortia. A similar trend was observed in the case of root and shoot lengths of the seedlings studied after 25 DAS (Table 4 and Fig. 10).

\section{In vivo screening of Trichoderma and Bacillus isolates against $X o O$ and $R$. solani}

Results obtained from the disease scoring using standard evaluation system (SES) under glass house 


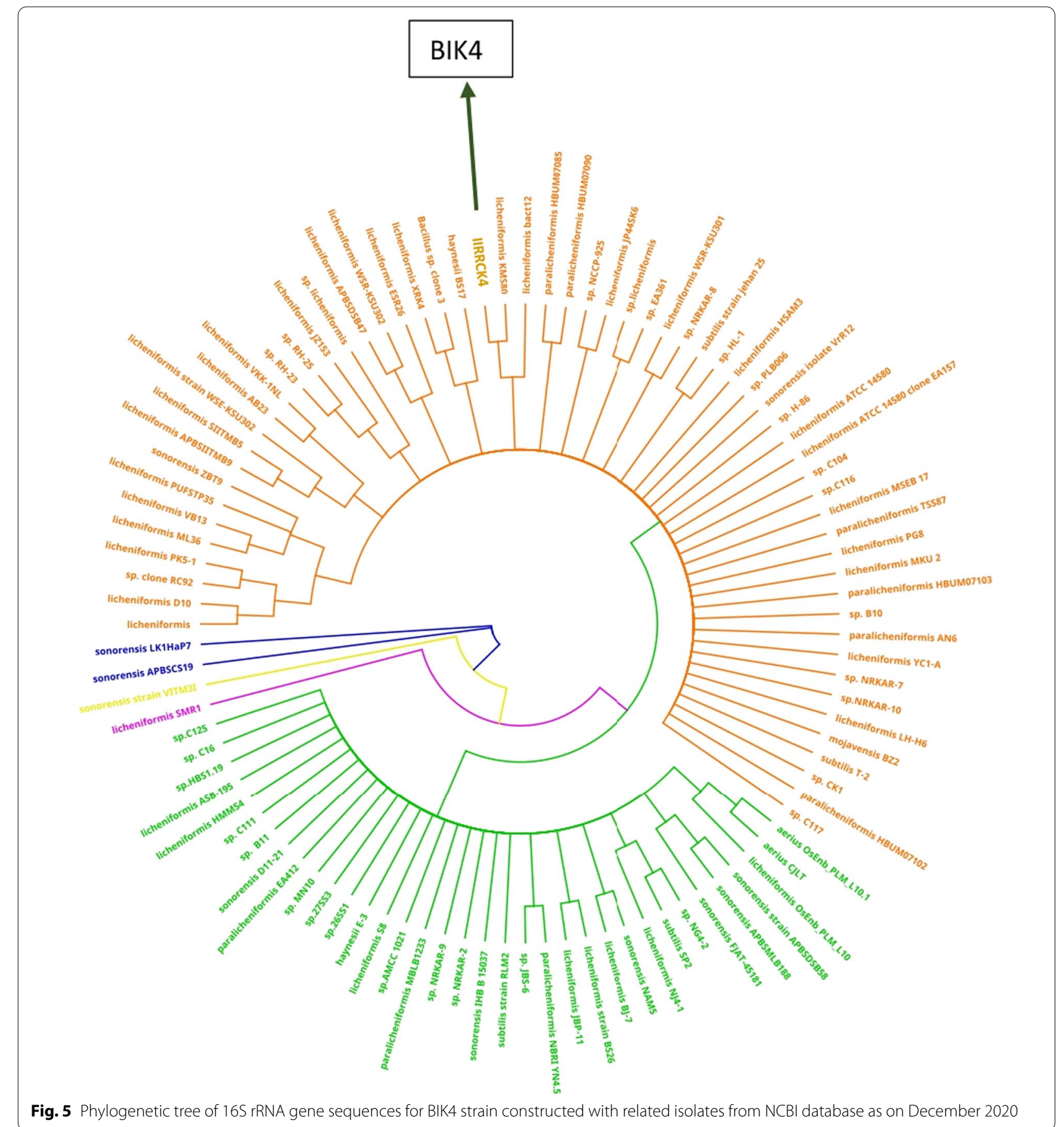

conditions indicated that the plants treated with the consortia of Trichoderma isolates had significantly less scores of sheath blight disease and the diseases scores of $\mathrm{BB}$ were significantly lesser in the plants treated with consortia of Bacillus isolates than other treatments. A comparative analysis between the progresses of lesion length and root/ shoot length showed inverse relationship for each of the treatments (Fig. 11). Further among the 2 most potential antagonists studied here, it was observed that TAIK 1 was more effective in improving plant growth than BIK 3.

\section{Discussion}

Biological control offers a viable alternative to the chemical management strategy for disease with no or very less genetic resistance in host plants (Ahemad and Kibret 


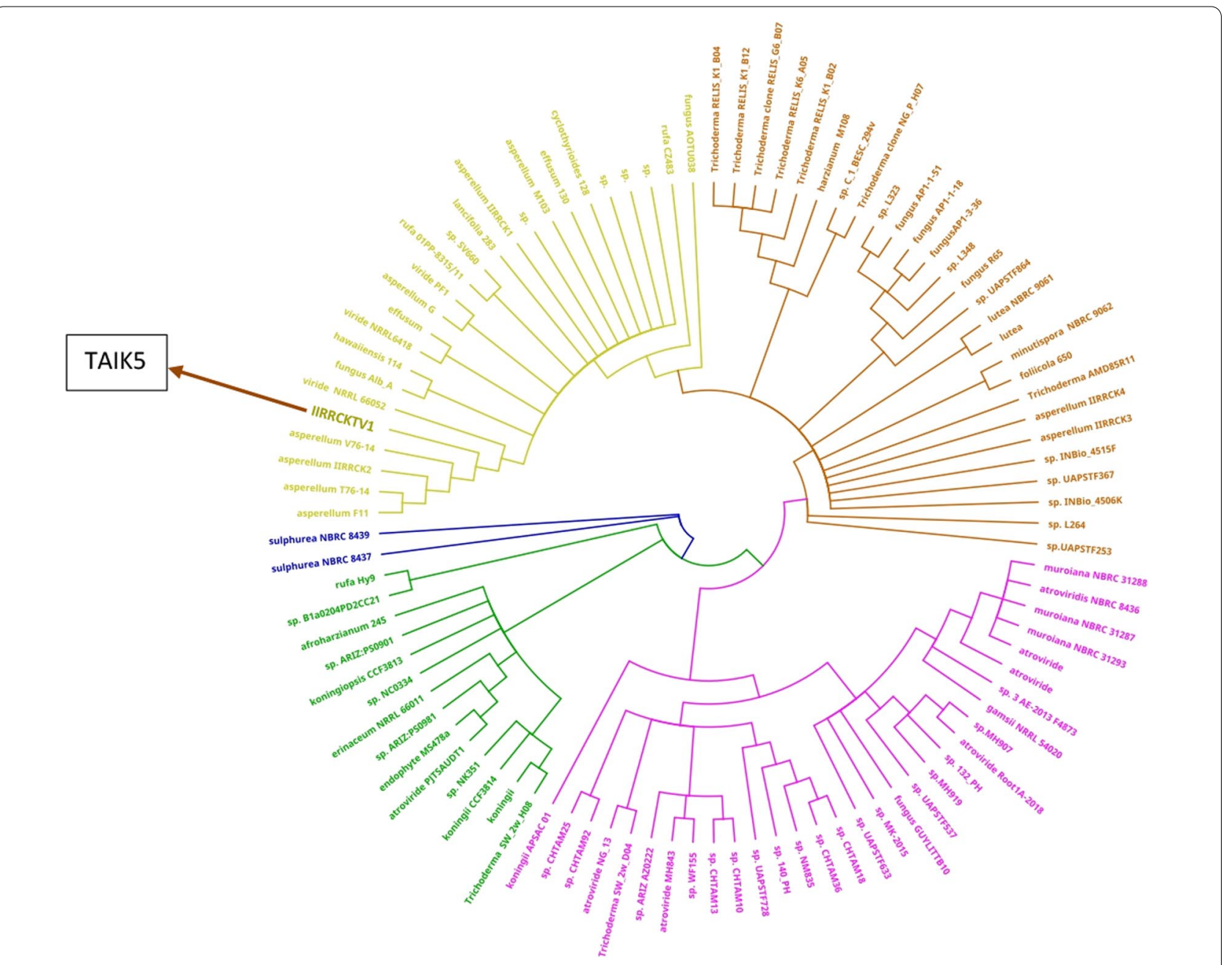

Fig. 6 Phylogenetic tree of 16 S rRNA gene sequences for TAIK5 strain constructed with related isolates from NCBI database as on December 2020

2014). However, for biocontrol strategy to be effective, the most important criteria are to find potential strains of antagonists that effectively suppress the pathogen under a broad set of environment and soil conditions, survive competitively in the introduced target areas and improve the overall development and yield of the crop (Pieterse et al. 2014). The present studies conclusively demonstrated the efficiency of native isolates of two major genera of bioagents, viz., Trichoderma and Bacillus against the two rice pathogens tested, viz., R. solani and $X o o$. Both bioagents are well known for their antagonistic potential and plant growth promoting activities.

Confirmation through molecular analysis compliments the conventional morphological and biochemical techniques. Molecular identification of microbial community requires specific primers for sequencing so as to get more accurate and precise results than the use of universal primers (Janda and Abbott 2007). In recent years, molecular diversity studies have changed the taxonomic classification of bacterial and fungal isolates. There are various other fungal micro-organisms which have been identified with the help of ITS sequencing technique (Lieckfeldt et al. 1999). Bacillus isolates were identified based on amplification of endoglucanase region of the $16 \mathrm{~S}$ rRNA, which is specific to directly identify particular species from 'B. subtilis group' (Mukherjee et al. 2017). Phylogenetic tree was constructed based on 16S rRNA and 18S rRNA gene sequence analysis of both bacterial and fungal antagonists, respectively. Sequence similarity within the isolates at nucleotide sequences level revealed differences within the isolates. However, unusual similarities exist for members of the 'Bacillus 16S rRNA group I', including B. subtilis, which displays $99.3 \%$ similarity at the $16 \mathrm{~S}$ rRNA level to $B$. atrophaeus and $98.3 \%$ to B. licheniformis and B. amyloliquefaciens (Ash et al. 1991). Thus, in order to be specific, endoglucanase specific primers were used and 2 isolates (BIK 2 and BIK 3 ) 
(See figure on next page.)

Fig. 7 a Nucleotide alignment of sequences in Bacillus strains. Nucleotide differences and insertions are highlighted. Note: The sample IDs 2CK, $3 C K$ and 4 CK represent BIK2, BIK3 and BIK4 strains, respectively. $\mathbf{b}$ nucleotide alignment of sequences in Trichoderma strains. Nucleotide differences and insertions are highlighted. The sample IDs CK2-T-2, CKTV-1, CK1-T-1, CK3-T-3 and CK4-T-4 represent TAIK2, TAIK5, TAIK1, TAIK3 and TAIK4 strains, respectively

among 3 Bacillus were found to be positive for endoglucanase, while the other were negative. But, sequence similarity index showed $98 \%$ identity with $B$. velezensis (BIK 2). These set of samples shall be further characterized using whole genome sequencing by this group.

Results from the dual plate assay indicated the decrease in radial growth of Xoo before coming in direct contact of Trichoderma isolates which could be because of release of antimicrobial compounds by Trichoderma in the medium. Several antimicrobial compounds, both volatile and non-volatile, have been identified from Trichoderma and were established to be effective against various plant pathogens in different crops (Reino et al. 2008). However, the direct growth of Trichoderma upon Xoo and the resulting reduction in the number of colonies of Xoo is an effect of utilization of the nutrients from the dead colonies of the bacteria, which were killed by the antimicrobial compounds of Trichoderma. Saprophytic growth of Trichoderma species has been well established (Steffan et al. 2020). In the case of $R$. solani, dual culture plate assay indicated that Trichoderma was able to parasitize the pathogen mycelia in a very aggressive manner and the growth of $R$. solani was severely inhibited. The sclerotia were also colonized and lost their ability to germinate effectively. Trichoderma colonizes, Rhizoctonia by means of release of cell wall degrading enzymes that helps them to penetrate inside the cell. Once inside the cell, Trichoderma engulfs the cell contents by converting complex molecules into simpler substances (Halifu et al. 2020). In in vitro assay of Bacillus against R. solani, the zone of inhibition exhibited by the colonies of Bacillus spp. confirmed the production of antibiotics, and in the later period they lose their original shape and texture. This denaturing effect of Bacillus on other pathogens was reported earlier (Huang et al. 2012). Cultural filtrate studies conducted against Xoo also showed the appropriate release and efficiency of bioactive compounds by Bacillus isolates. Co-cultivation studies with transmission electron microscopy analysis indicated concentration of Bacillus inside the cytoplasm of Xanthomonas leading to altered surface morphology resulted in the leakage and further shrinkage of the cells (Xie et al. 2018).

Earlier studies by this group on the key role of Trichoderma spp. in increasing the germination percentage, seedling length and seedling dry weight of rice were found to be by direct production of growth regulating hormones (Chinnaswami et al. 2021). Similarly, members of Bacillus were reported to induce cytokinin, a cell division promoting growth related hormone, which was found to enhance the seedling growth and development (Arkhipova et al. 2005). Growth improvement in seedlings may also be due to the increase in production of amylase (exogenous modulators) which hydrolyses the starch into simple sugars and in turn provides energy for growth of roots and shoots in germinating seedlings. Biocontrol activities of both the bioagents tend to stimulate defence system in plants, which includes production of PR proteins, phytoalexins and activation of induced systemic resistance (ISR) by synthesis of jasmonic acid, ethylene and NPR-1 regulatory gene (Konappa et al. 2020).

\section{Conclusions}

Several antagonistic bacteria and fungi belonging to the genus Bacillus and Trichoderma were isolated from the native rice soils from in and around Hyderabad, Telangana. The isolates were screened in vitro for their antagonistic efficiency and the selected potential isolates were carried forward for further identification and antagonistic studies tested against the two major rice pathogens, viz., $R$. solani and Xoo. Identification based on morphological characters were confirmed using molecular tools. Accordingly, phylogenetic tools based on 16srRNA and ITS gene sequences were used for identifying the isolates of Trichoderma and Bacillus at species level. The diversity analysis was suitable alternative method to phenotypic procedures for reliable identification of unknown isolates at species level or at least useful in the primary differentiation at species level from those of other groups. The individual isolates of the 2 antagonists varied in their efficiency to suppress the pathogens and promote plant growth. Consortia of the isolates were found to be more effective than the individual ones. Among the different isolates, the results obtained indicated the highest antagonistic efficiency of two native isolates TAIK 1 and BIK 3 against the two major pathogens of rice. In addition, the bioagents also enhanced the root and shoot growth of rice, indicating a health plant growth to defend against the pathogens. 
A $4 c$

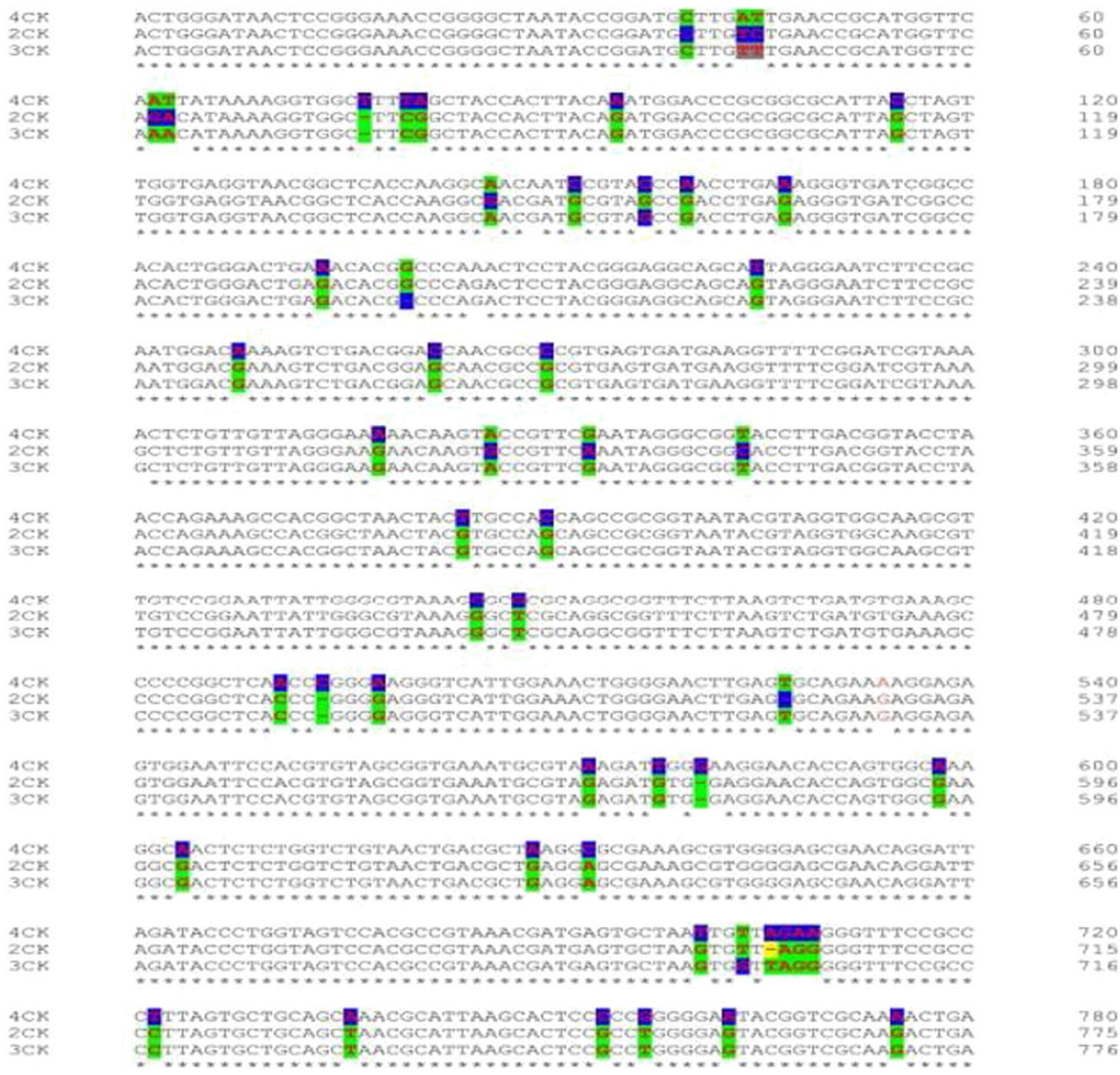
9

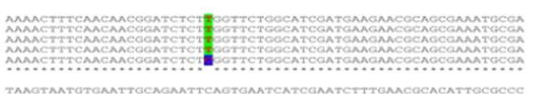

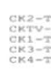

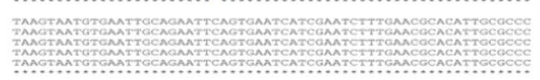

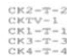

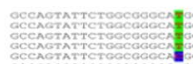

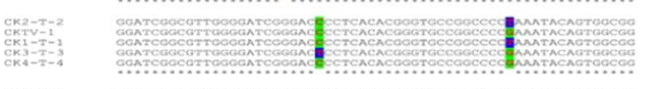

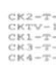

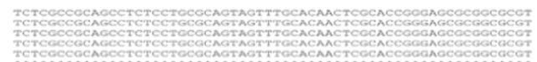

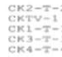
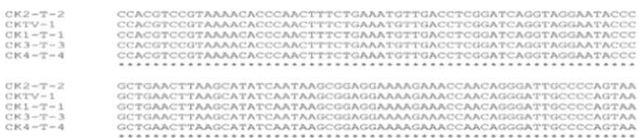

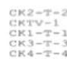
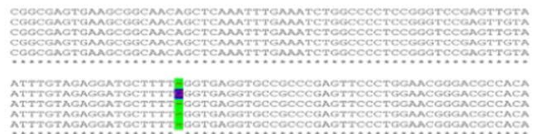

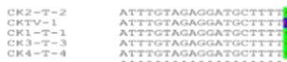

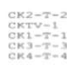

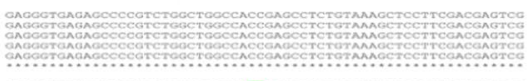

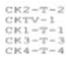
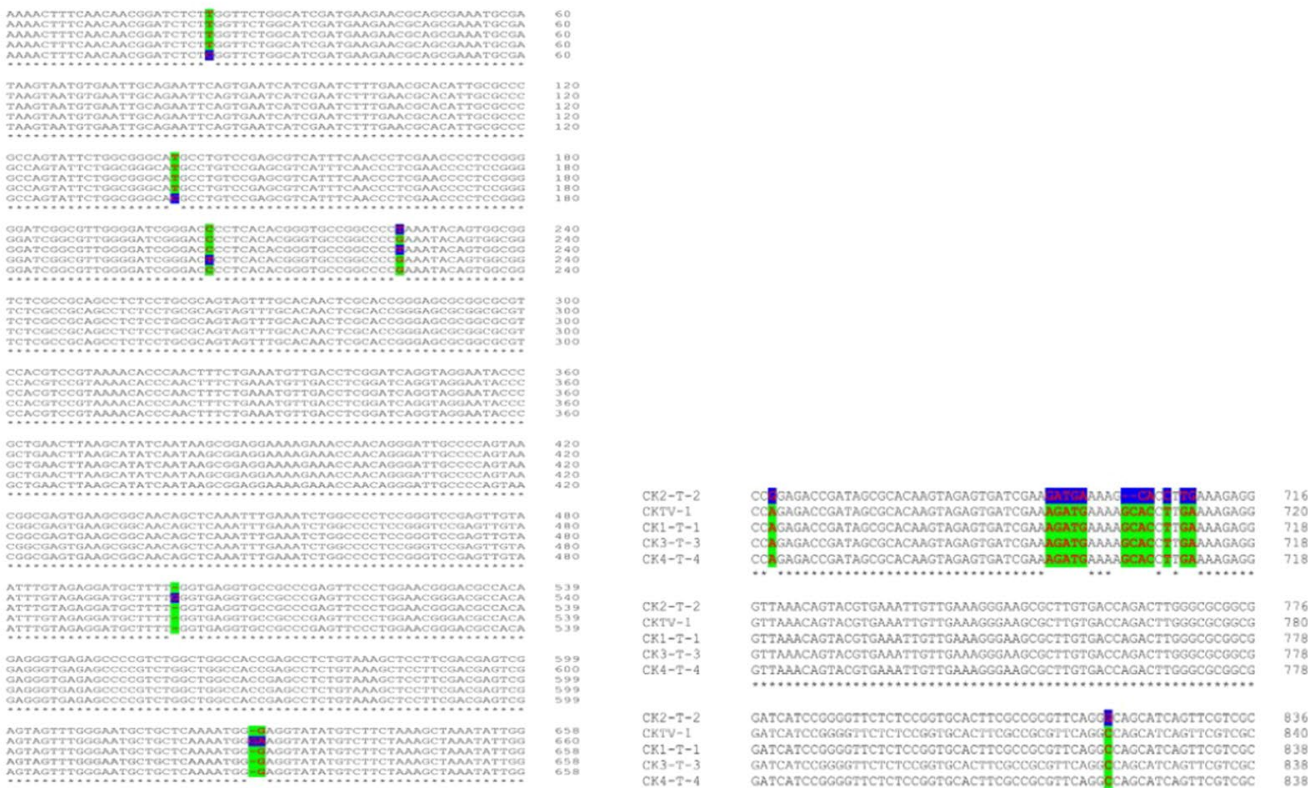

GTTAAACAGTACGTGAAATTGTTGAAAGGGAAGCGCTTGTGACCAGACTTGGGCGCGGCG

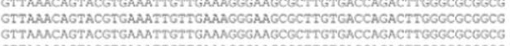
GTPAAACAGTACGIGAAATTGITGAAAGGGAAGCGCTIGTGACCAGACTTGGGCGCGGCG GATCATOCOOCOTTCTCTOCOOTGCACTRCOCCOCOTTCA GATCATCCGGGGTTCTCTCCGGTCAACHTCGCCGCGITCAGA

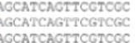
AATCATCCGGGGTTCTCTOCGGTGCACTTCGCCGCGTRCAGG KAGCAATCAGTTCGTCGC

Fig. 7 (See legend on previous page.) 

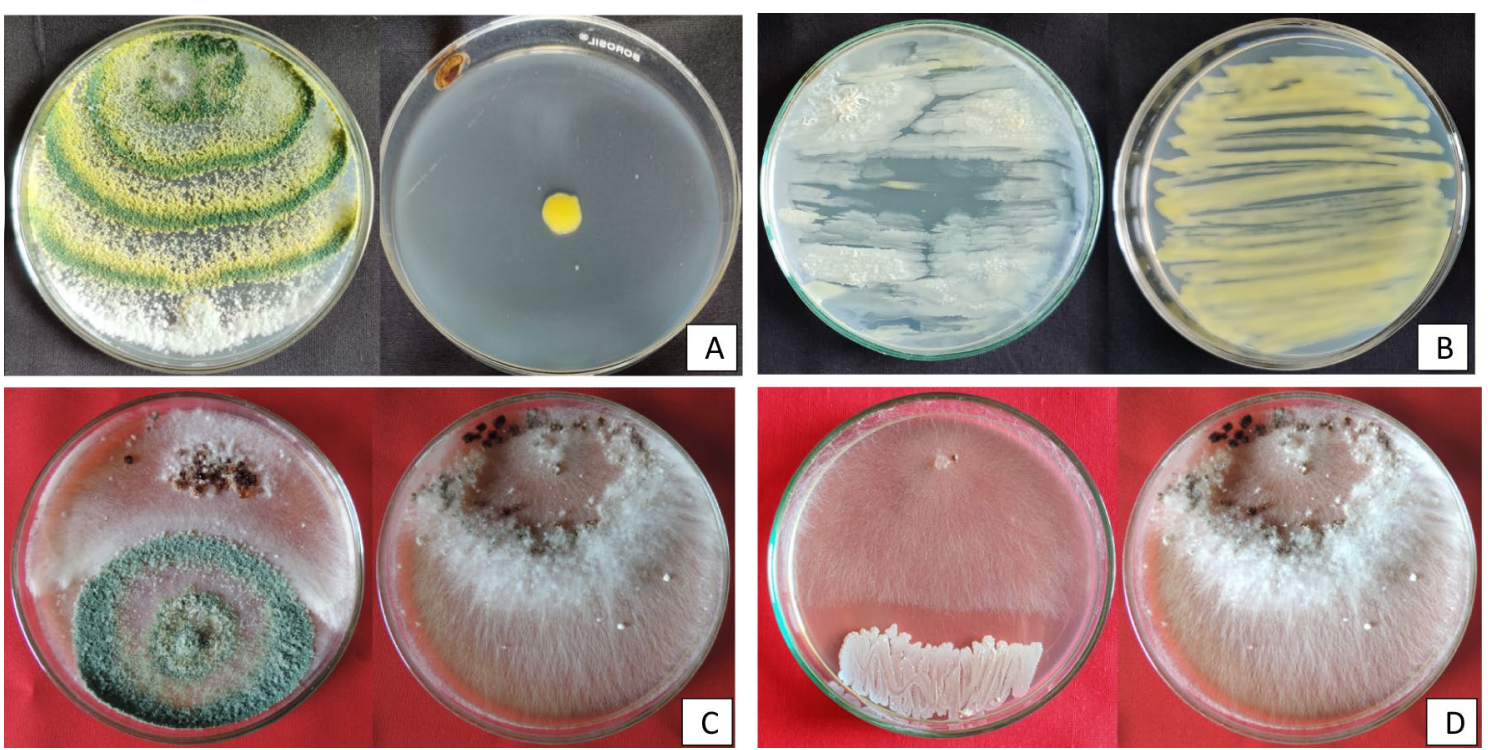

Fig. 8 In vitro efficiency of bioagents against Xoo and R. solani. a Antagonism of TAIK1 on Xoo in MWM (left) and Xoo control, b overgrowth of BIK3 upon Xoo in MWM (left) and Xoo control, $\mathbf{c}$ antagonism of TAIK1 on R. solani in PDA (left) and R. solani control, $\mathbf{d}$ antagonism of BIK3 on R. solani in PDA and R. solani control

\section{Fig. 1a}

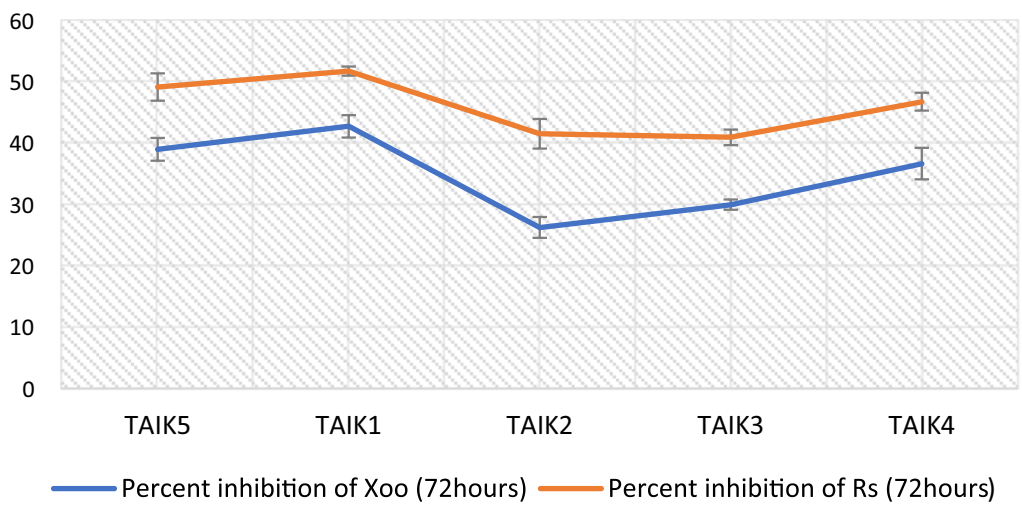

Fig. 1b
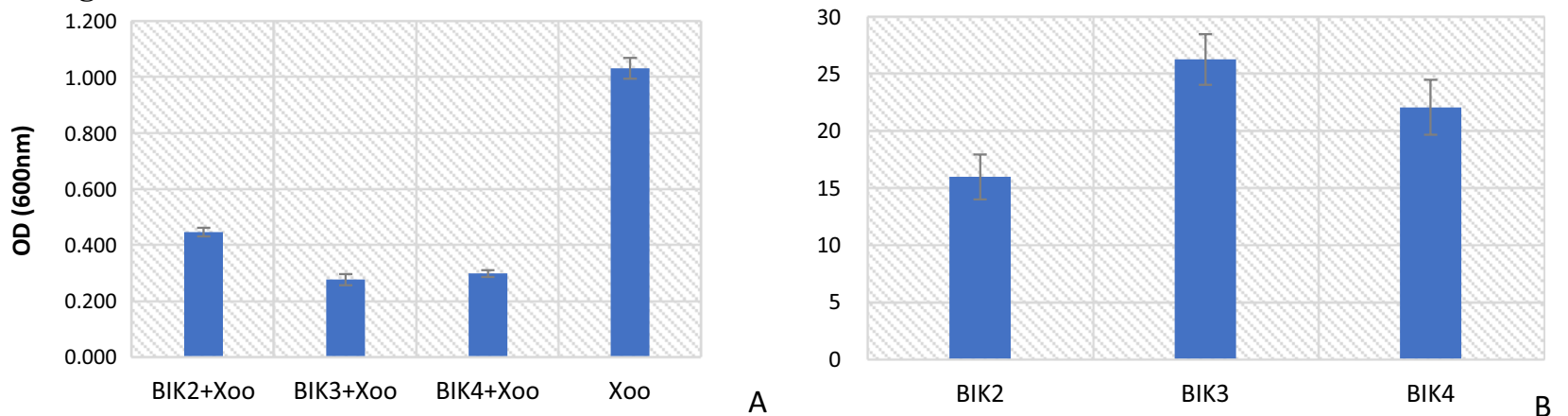

Fig. 9 a: In vitro screening of different isolates of Trichoderma spp. against Xoo and R. solani. Data represent mean of three replications in each treatment. X-axis represents the five isolates of Trichoderma taken for the dual culture assay. $\mathbf{b}$ : In vitro screening of different isolates of Bacillus spp. against $X_{0} \circ$ and $R$. solani. Data represent mean of three replications in each treatment. A: $O_{600 n m}$ values of sample containing culture filtrate $(75 \%$ concentration) of different Bacillus isolates incubated with Xoo for $72 \mathrm{~h}$. B: Percent inhibition of R. solani by Bacillus isolates after $72 \mathrm{~h}$ of incubation 
Table 4 Screening of PGPR activities of isolated antagonists in TN1

\begin{tabular}{|c|c|c|c|c|c|}
\hline Isolates & $\begin{array}{l}\text { Root length }(\mathrm{cm}) \\
\text { 25th DAS }\end{array}$ & $\begin{array}{l}\text { Shoot length }(\mathrm{cm}) \\
\text { 25th DAS }\end{array}$ & Germinations \% & $\begin{array}{l}\text { Vigour index-1 (10th } \\
\text { day after germination) }\end{array}$ & $\begin{array}{l}\text { Vigour index-2 } \\
\text { (10th day after } \\
\text { germination) }\end{array}$ \\
\hline TAIK1 & $9.90^{b}$ & $13.20^{\mathrm{bc}}$ & 100 & $610.33^{i}$ & $17.00^{\text {de }}$ \\
\hline TAIK2 & $7.50^{\mathrm{ab}}$ & $11.07^{\mathrm{abc}}$ & 92 & $378.67^{\mathrm{b}}$ & $10.31^{\mathrm{b}}$ \\
\hline TAIK3 & $7.53^{\mathrm{ab}}$ & $10.27^{\mathrm{abc}}$ & 90 & $404.77^{c}$ & $11.19^{b c}$ \\
\hline TAIK4 & $8.57^{\mathrm{ab}}$ & $12.23^{b c}$ & 92 & $460.00^{e}$ & $12.24^{\mathrm{bcd}}$ \\
\hline TAIK5 & $8.83^{\mathrm{ab}}$ & $12.47^{\mathrm{bc}}$ & 98 & $539.00^{f}$ & $13.25^{\text {bcde }}$ \\
\hline BIK2 & $7.87^{\mathrm{ab}}$ & $9.63^{\mathrm{ab}}$ & 96 & $442.33^{d}$ & $11.83^{b c}$ \\
\hline BIK3 & $8.63^{\mathrm{ab}}$ & $13.13^{\mathrm{bc}}$ & 100 & $560.00^{9}$ & $15.11^{\text {bcde }}$ \\
\hline BIK4 & $7.97^{\mathrm{ab}}$ & $10.47^{\mathrm{abc}}$ & 98 & $470.00^{e}$ & $13.09^{b c d}$ \\
\hline Trichoderma isolates consortia & $10.17^{b}$ & $14.07^{d}$ & 100 & $640.67^{j}$ & $18.13^{e}$ \\
\hline Bacillus isolates consortia & $9.40^{\mathrm{ab}}$ & $13.53^{b c}$ & 100 & $590.67^{h}$ & $15.66^{\text {cde }}$ \\
\hline Healthy control & $6.00^{\mathrm{a}}$ & $7.77^{\mathrm{a}}$ & 84 & $312.00^{\mathrm{a}}$ & $5.44^{\mathrm{a}}$ \\
\hline
\end{tabular}

Data represent mean of three replications. Numerical values with different letters are significantly different $(P<0.05$, DMRT, SPSS)

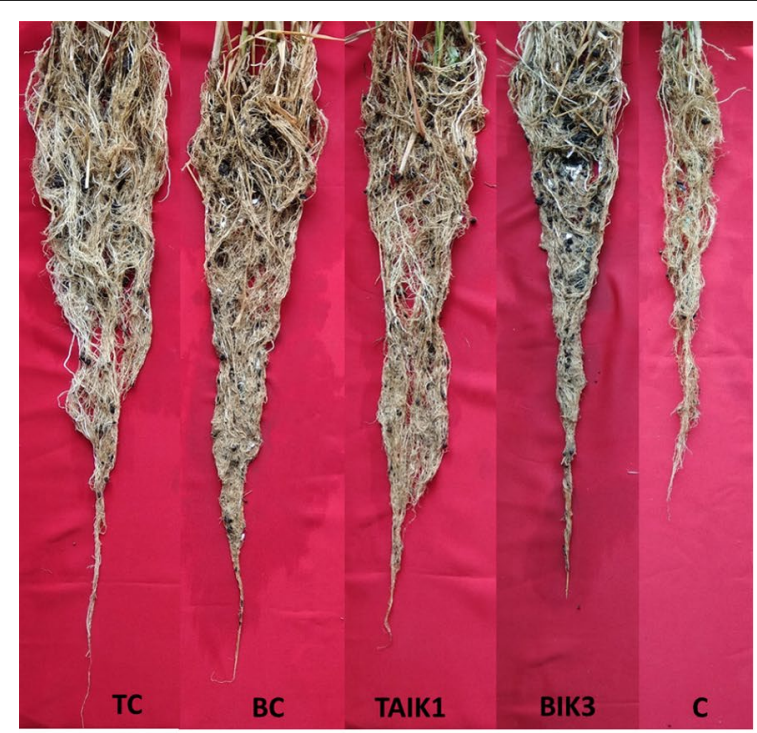

A

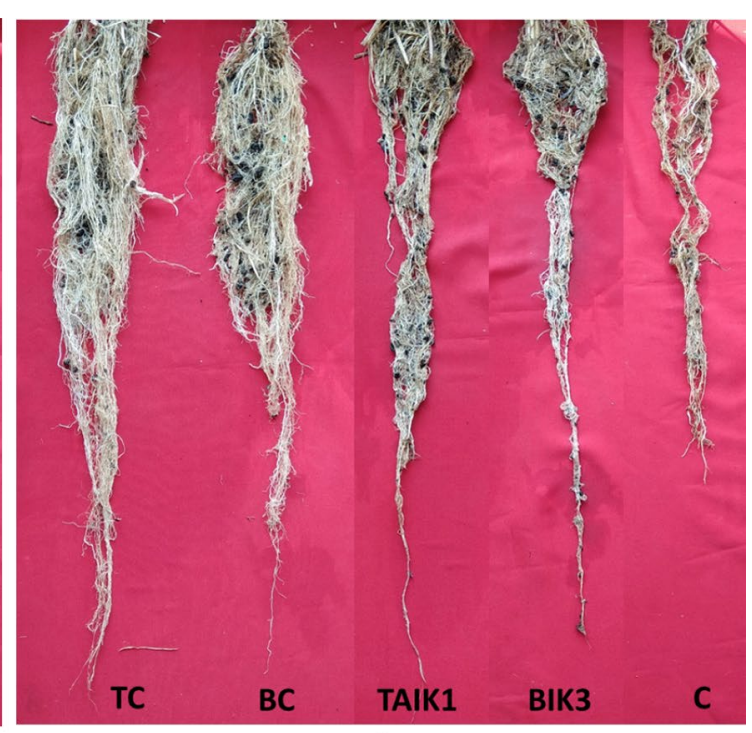

B

Fig. 10 Changes in root length of plants treated with bioagents and inoculated with pathogens. Root length of TN1 after 20 days of Xoo (a) and R. solain (b) infection. TC: Trichoderma consortia, BC: Bacillus consortia, C: Control

\section{Abbreviations}

BB: Bacterial blight; Xoo: Xanthomonas oryzae Pv. oryzae; R. solani: Rhizoctonia solani; ROS: Reactive oxygen species; ITS: Internal transcribed spacer; TSM: Trichoderma Specific medium; PYEM: Peptone yeast extract medium; SEM: Scanning electron microscopy; LB: Luria Bertani; PDB: Potato dextrose broth; PCR: Polymerase chain reaction; NCBI: National Center for Biotechnology Information; BLAST: Basic local alignment research tool; OD: Optical density; CMC: Carboxymethyl cellulose; $\mathrm{H}_{2} \mathrm{O}_{2}$ : Hydrogen peroxide; APx: Ascorbate peroxidase; CAT: Catalase.

\section{Acknowledgements}

The authors acknowledge ICAR-Indian Institute of Rice Research for support in the research work conducted.

\section{Authors' contributions}

All authors have read and approved the manuscript. Conceptualization and review were done by CK. Collection of materials and preparation of the draft were maintained by DM. Editing of written text was done by GR and SKH. PM has assisted in conducting experiments. Editing of manuscript was done by RMS. All authors read and approved the final manuscript.

\section{Funding}

The authors thank Indian Council of Agricultural Research, New Delhi, for funding the research project by means of salary and infrastructure.

\section{Availability of data and materials}

Data and materials in this study can be available on reasonable request. 

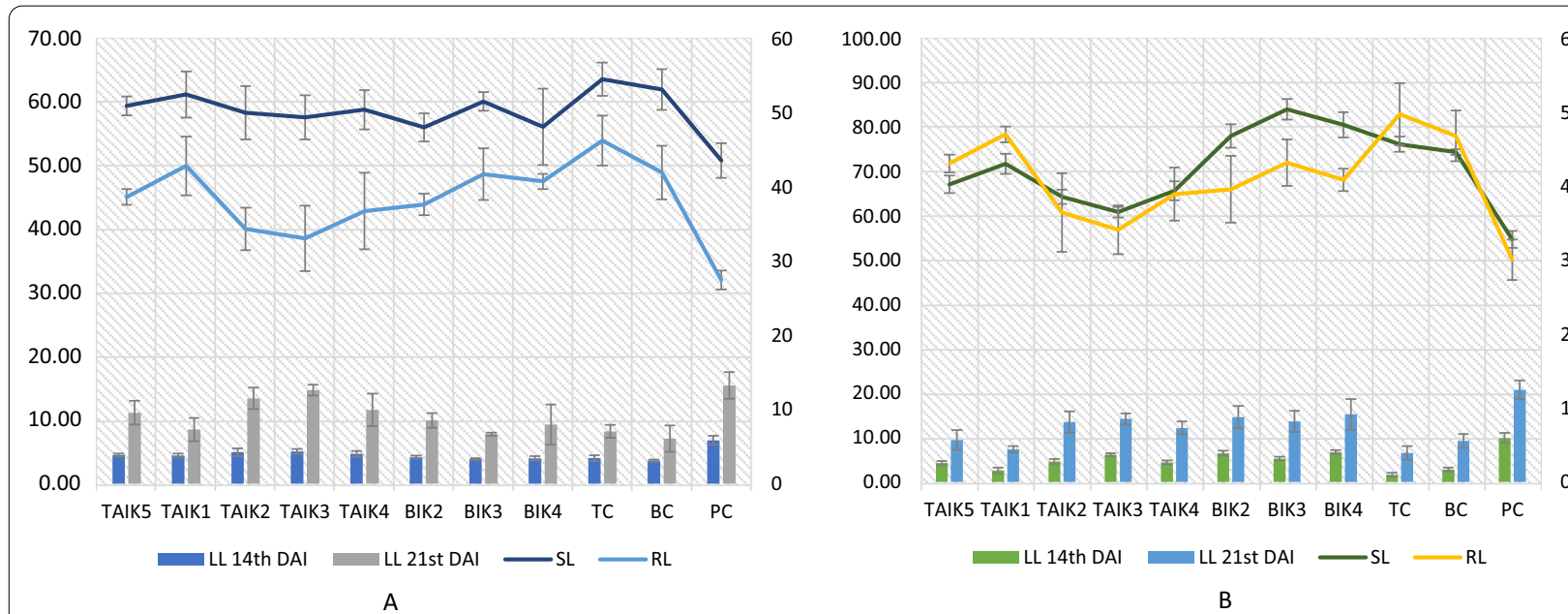

Fig. 11 Screening of bacterial blight and sheath blight diseases of rice against isolated fungal and bacterial bioagents. Data represent the mean of three replications $\left(P^{<} 0.05\right.$, Duncan's multiple range test, SPSS). $C D(P=0.05)$. The combo graph depicts relationship between disease progress (lesion length at 14th DAl and 21st DAl) and change in root and shoot length. a Bacterial blight. b Sheath blight. TC: Trichoderma consortia, BC: Bacillus consortia, PC: pathogen control

\section{Declarations}

\section{Ethics approval and consent to participate}

Not applicable.

\section{Consent for publication}

Not applicable.

\section{Competing interests}

No potential conflict of interest was reported by the author(s).

\section{Author details}

${ }^{1}$ Department of Plant Pathology, ICAR-IIRR, Hyderabad, Telangana, India. ${ }^{2}$ Department of Plant Pathology, Professor Jayashankar Telangana State Agricultural University, Hyderabad, Telangana, India. ${ }^{3}$ Department of Agricultural Biotechnology, ICAR-IIRR, Hyderabad, Telangana, India.

Received: 28 May 2021 Accepted: 19 August 2021

Published online: 25 August 2021

\section{References}

Abo-Elyousr KA, Bagy HMK, Hashem M, Alamri SA, Mostafa YS (2019) Biological control of the tomato wilt caused by Clavibacter michiganensis subsp. michiganensis using formulated plant growth-promoting bacteria. Egypt J Biol Pest Control 29(1):1-8

Ahemad M, Kibret M (2014) Mechanisms and applications of plant growth promoting rhizobacteria: current perspective. J King Saudi Univer Sci 26(1):1-20

Arkhipova TN, Veselov SU, Melentiev Al, Martynenko EV, Kudoyarova GR (2005) Ability of bacterium Bacillus subtilis to produce cytokinins and to influence the growth and endogenous hormone content of lettuce plants. Plant Soil 272(1):201-209

Ash C, Farrow JA, Dorsch M, Stackebrandt E, Collins MD (1991) Comparative analysis of Bacillus anthracis, Bacillus cereus, and related species on the basis of reverse transcriptase sequencing of $16 \mathrm{~S}$ rRNA. Int J Syst Bacteriol 41:343-346

Ashe S, Maji UJ, Sen R, Mohanty S, Maiti NK (2014) Specific oligonucleotide primers for detection of endoglucanase positive Bacillus subtilis by PCR. 3 Biotech 4:461-465. https://doi.org/10.1007/s13205-013-0177-6

Beal J, Farny NG, Haddock-Angelli T, Selvarajah V, Baldwin GS, Buckley-Taylor R, Gershater M, Kiga D, Marken J, Sanchania V, Sison A (2020) Robust estimation of bacterial cell count from optical density. Commun Bio $3(1): 1-29$

Bozzola JJ, Russell LD (1999) Electron microscopy: principles and techniques for biologists. Jones \& Bartlett Learning, Burlington

Cavaglieri L, Passone A, Etcheverry M (2004) Screening procedures to select rhizobacteria with biocontrol activity upon Fusarium verticillioides growth and fumonisin B1 production. Res Microbiol 155:747-754

Chinnaswami K, Mishra D, Miriyala A, Vellaichamy P, Kurubar B, Gompa J, Madamsetty SP, Raman MS (2021) Native isolates of Trichoderma as biosuppressants against sheath blight and stem rot pathogens of rice. Egypt J Biol Pest Control 31(1):1-10

Chukwu SC, Rafii MY, Ramlee SI, Ismail SI, Hasan MM, Oladosu YA, Magaji UG, Akos I, Olalekan KK (2019) Bacterial leaf blight resistance in rice: a review of conventional breeding to molecular approach. Mol Biol Reptr 46(1):1519-1532

Elshakh AS, Anjum SI, Qiu W, Almoneafy AA, Li W, Yang Z, Cui ZQ, Li B, Sun GC, Xie GL (2016) Controlling and defence-related mechanisms of Bacillus strains against bacterial leaf blight of rice. J Phytopathol 164(7-8):534-546

Gams W, Bissett J (1998) Morphology and identification of Trichoderma. In: Kubicek CP, Harman GE (eds) Trichoderma and Gliocladium, vol 1. Taylor and Francis, London, pp 1-34

Gangwar GP, Sinha AP (2010) Comparative antagonistic potential of Trichoderma spp. against Xanthomonas oryzae pv. oryzae. Ann Plant Prot Sci $18(2): 458-463$

Gnanamanickam SS (2009) Biological control of rice diseases, vol 8. Springer, Berlin

Halifu S, Deng X, Song X, Song R, Liang X (2020) Inhibitory Mechanism of Trichoderma virens ZT05 on Rhizoctonia solani. Plants 9(7):912

Huang X, Zhang N, Yong X, Yang X, Shen Q (2012) Biocontrol of Rhizoctonia solani damping-off disease in cucumber with Bacillus pumilus SQR-N43. Microbiol Res 167(3):135-143

Janda JM, Abbott SL (2007) 16S rRNA gene sequencing for bacterial identification in the diagnostic laboratory: pluses, perils, and pitfalls. J Clin Microbiol 45(9):2761-2764

Kannan C, Pradhan B, Renuka R, Anila R, Prakasam V, Prasad MS, Sundaram RM, Sudhakar R (2018) Characterization of native rice specific isolates of Trichoderma and evaluation of its effect on sheath blight pathogen Rhizoctonia solani. J Rice Res 11(1):52-56

Ke Y, Hui S, Yuan M (2017) Xanthomonas oryzae pv. oryzae inoculation and growth rate on rice by leaf clipping method. Bio-protocol 7(19) 
Köhl J, Kolnaar R, Ravensberg WJ (2019) Mode of action of microbial biological control agents against plant diseases: relevance beyond efficacy. Front Plant Sci 10:845

Konappa N, Krishnamurthy S, Arakere UC, Chowdappa S, Ramachandrappa NS (2020) Efficacy of indigenous plant growth-promoting rhizobacteria and Trichoderma strains in eliciting resistance against bacterial wilt in a tomato. Egypt J Bio Pest Control 30(1):1-13

Lieckfeldt E, Samuels GJ, Nirenberg HI, Petrini O (1999) A morphological and molecular perspective of Trichoderma viride: is it one or two species? Appl Environ Microbiol 65(6):2418-2428

Marzano M, Gallo A, Altomare C (2013) Improvement of biocontrol efficacy of Trichoderma harzianum vs. Fusarium oxysporum f. sp. lycopersici through UV-induced tolerance to fusaric acid. Biol Control 67:397-408

Mukherjee PK, Horwitz BA, Herrera-Estrella A, Schmoll M, Kenerley CM (2013) Trichoderma research in the genome era. Ann Rev Phytopathol 51:105-129

Mukherjee B, Anuroopa N, Uma Maheswari N (2017) Biochemical and molecular characterization of different Bacillus sp. from the Rhizosphere soil of Withania somnifera. Int J Pharm Sci Rev Res 43(2):178-184

Pieterse CM, Zamioudis C, Berendsen RL, Weller DM, Van Wees SC, Bakker PA (2014) Induced systemic resistance by beneficial microbes. Ann Rev Phytopathol 52

Reino JL, Guerrero RF, Hernández-Galán R, Collado IG (2008) Secondary metabolites from species of the biocontrol agent Trichoderma. Phytochem Rev 7(1):89-123

Siddiqui IA, Shaukat SS (2003) Combination of Pseudomonas aeruginosa and Pochonia chlamydosporia for control of root infecting fungi in tomato. J Phytopathol 151:215-222
Sinclair JB, Dhingra OD (2017) Basic plant pathology methods. CRC Press, Boca Raton, pp 287-300

Singh A, Rohilla R, Singh US, Savary S, Willocquet L, Duveiller E (2002) An improved inoculation technique for sheath blight of rice caused by Rhizoctonia solani. Can J Plant Pathol 24(1):65-68

Sneath PHA (1986). In: Holt JG (ed) Berger's manual of determinative bacteriology. Williams \& Wilkins, Baltimore, pp 1105-1139 (1288-1301)

Steffan BN, Venkatesh N, Keller NP (2020) Let's get physical: bacterial-fungal interactions and their consequences in agriculture and health. J Fungi 6(4):243

Xie S, Zang H, Wu H, Uddin Rajer F, Gao X (2018) Antibacterial effects of volatiles produced by Bacillus strain D13 against Xanthomonas oryzae pv. oryzae. Mol Plant Pathol 19(1):49-58

Youssuf AG, Nemmat AH, Al-Qurashi AA (2014) Molecular characterization of Trichoderma populations isolated from soil of Taif City, Saudi Arabia. Int J Curr Microbiol Appl Sci 3(9):10

Yugander A, Ladhalakshmi D, Prakasham V, Mangrauthia SK, Prasad MS, Krishnaveni D, Madhav MS, Sundaram RM, Laha GS (2015) Pathogenic and genetic variation among the isolates of Rhizoctonia solani (AG 1-IA), the rice sheath blight pathogen. J Phytopathol 163(6):465-474

\section{Publisher's Note}

Springer Nature remains neutral with regard to jurisdictional claims in published maps and institutional affiliations.

\section{Submit your manuscript to a SpringerOpen ${ }^{\circ}$ journal and benefit from:}

- Convenient online submission

- Rigorous peer review

- Open access: articles freely available online

- High visibility within the field

- Retaining the copyright to your article

Submit your next manuscript at $\boldsymbol{\nabla}$ springeropen.com 